\title{
Transformation of the Political System of Saudi Arabia: Regional Dimension
}

\author{
Abdullah Hazaa Othman ${ }^{1}$, Oleg Evgenievich Grishin ${ }^{2}$, M. Yoserizal Saragih ${ }^{3}$, Mulyadi $^{4}$ \\ ${ }^{1,2}$ Department of Political Analysis and Management, RUDN University, Moscow, Russia \\ ${ }^{3}$ Universitas Islam Negeri Sumatera Utara, Medan, Indonesia \\ ${ }^{4}$ Faculty of Social Science and Political Science, Universitas Malikussaleh Aceh, Indonesia \\ abdollah.othman1985@gmail.com; Yosesaragih77@gmail.com; mulyadi_mm@unimal.ac.id
}

\begin{abstract}
The Kingdom of Saudi Arabia is considered one of the pivotal countries in the region and the international community due to its political and economic weight. The importance of this role comes with the Saudi weight in the Arab Gulf and the importance of the Gulf for the Kingdom's security in general, as well as being at the forefront of the countries bordering the Gulf in terms of the volume of output and oil reserves. Since the year 2010, changes in the regional environment of the Kingdom of Saudi Arabia have pushed towards reconsidering some of the problems and challenges to which its policy was exposed, and it has moved towards searching for what it deems best to enhance its security and stability in the region. However, this role is faced with internal, economic, political, social, regional and international challenges, The need to adapt in the formation of its positions on regional issues, in line with the changes that occurred in the structure of the Arab regional system and the decline in the position of some regional actors, which led to the multiplicity of Saudi regional proposals to formulate its strategic directions to confront the state of imbalance in the region, in addition to that. Its keenness to fulfill its obligations towards its regional allies, as is the case in Yemen, Saudi Arabia has benefited from being an effective regional state, but its effectiveness must be negatively affected by what is happening on or around its territory. And that future expectations do not serve this role much.
\end{abstract}

\section{Keywords}

the Saudi political system the Arab Gulf states, regional transformations, challenges

\section{Introduction}

The Arab region witnessed the waves of the popular movement, which was known as the Arab Spring revolution since the end of 2010 and the beginning of 2011, which generated a set of challenges, which the countries of the region had to face and find approaches on the level of their foreign policy to deal with them, and the Kingdom of Saudi Arabia was at the forefront under Its repercussions are now reflected on its national security and regional stability, The Saudi leadership's perceptions of these developments, especially after the wave of change due to the revolutions and protest movements that swept many Arab countries, and the occurrence of shifts in the balance of power in favor of non-Arab parties (Iran, Turkey, Israel) due to the retreat of their regional balance, and the retreat of Arab countries on their internal problems, which is a prayer To modify the Saudi strategic performance in a way that is consistent with those events and variables, so there has been talk about the effective role of the Saudi regime in the Middle East region, which is not limited to political influence, but rather includes religious and economic dimensions that helped crystallize and escalate this regional position in the Saudi system, 
Konfrontasi Journal: Culture, Economy and Social Changes, 7 (3) September 2020, 237-245

ISSN: 1410-881X (Print), 2716-2095 (Online)

Abdullah Hazaa Othman, Oleg Evgenievich Grishin, M. Yoserizal Saragih; Mulyadi: Transformation
of the Political System of Saudi Arabia: Regional Dimension
DOI: https://doi.org/10.33258/konfrontasi2.v7i3.119
http://www.konfrontasi.net/index.php/konfrontasi2

and $\mathrm{He}$ made attempts to contain non-Arab powers, as well as Iranian expansion in the region, through their interactions with their regional neighborhood and to prevent any threat to their national security, and their ability to impose their narration in presenting themselves as a factor in regional interactions.

\section{Discussion}

Research in this article covers: Transformation of the Political System of Saudi Arabia: Regional Dimension, It is divided into three stages:

\subsection{Internal Variables Affecting the Trends of Saudi Mobility}

The transformations in the Arab region are the result of the revolutions and the change movement that began in late 2010 and early 2011, a major turning point in redrawing and reshaping the features of a new phase, including the birth of new governments and regimes different from what was prevalent and the rule of different social values.

The Saudi regime achieved "relative success" in overcoming the sporadic protests in the country in the spring of 2011, especially the so-called "Hunayn Revolution" on March 11, 2011, which some Saudi activists called for political reform called for, without achieving tangible success ${ }^{1}$. The protests failed to turn into a popular movement demanding the overthrow of the regime, which was interpreted at the time as the manufacture of a distributable power in an oil-state system, the Saudis 'satisfaction with their leadership, and external support the regime received from its Western allies, led by the United States ${ }^{2}$. The process of change in Saudi Arabia's policy in dealing with regional issues has been linked to transformations in the political system in it, and its awareness of the size of the decline in the role and position of the United States, and that it is waging its battle in the confrontation alone, whether on the level of internal or external challenges ${ }^{3}$. As the Saudi active move towards regional crises stems from an awareness of the potential risks, which dictate that the Kingdom should be a more influential party in the form and pattern of interactions prevailing in the region ${ }^{4}$.

In the past years, during the reign of the previous King Abdullah bin Abdul-Aziz, Saudi Arabia faced many failures in light of its domestic and regional policies, due to a number of reasons, including the divisions within the royal family or the absence of a strategic vision towards Gulf commitments and regional problems and the escalation of terrorism and sectarian tension in the region.

The Kingdom of Saudi Arabia was not immune to the changes that the region had witnessed. Political movements took place in more than one region and on more than one level during 2011 and 2012, and about seven statements were issued calling for reform, and many regions witnessed demonstrations calling for reform (especially the Eastern Region, the Qassim region, and at King Khalid University in Abha), in addition to the strikes that took

\footnotetext{
${ }^{1}$ Abdul Khaleq Abdullah, "The Arab Spring: A View from the Arab Gulf," Al-Mustaqbal Al-Arabia, No. 391, September 2011, p. 122.

2 Madawi Al-Rasheed, "The Future of Reform Demands in Saudi Arabia," Beirut: Center for Arab Unity Studies and the Swedish Institute in Alexandria, January 2016, p. 671.

${ }^{3}$ Muhammad Abdul Salam, How will relations be managed in the next stage, Al Siyasa Al Dawliya magazine Issue 186, Al-Ahram Institute for Strategic Studie.

${ }^{4}$ Salih Al-Nu'mani, The Israeli Strategic Mind: A Reading in the Arab Revolutions and an Examination of Their Fate Beirut, Arab House,2013,p,32. https://www.elsiyasa-online.com/2020/01/The-Israeli-Strategic.html
} 
place. Pervaded major companies ${ }^{5}$. In the following years, the Kingdom had to confront terrorist activities and the operations of armed organizations on its soil.

Although the Kingdom has made tangible progress in the Human Development Report of the United Nations Development Program for the year 2014, as it ranked 34th in the world compared to the 57 th in the 2013 report, it is joined to the group of countries with very high human development, It also ranked second in the Arab world and the Gulf, and tenth in the G20, which is a positive development ${ }^{6}$, However, the problems and demands associated with reform did not stop at this stage. There is an imbalance in the economic structures in an economic rentier country dominated by state capitalism and determining its mode of production. There is no difference between the oil and development policies ${ }^{7}$, The need for reform is linked to the reality of a society dependent on its social formations on the tribe at a time when constitutional concepts of citizenship, rights, and duties prevail in the world, which has made society lose its citizenship identity.

Accordingly, the state realized that it needs to restructure its foreign political and national security institutions so that it moves internationally in a manner commensurate with the importance and political, economic and religious influence it enjoys, based on the fact that changing societies forces states to adapt to this change and respond to it, otherwise it will lead to the emergence of A big gap between society on the one hand, and political society or the state on the other ${ }^{8}$.

Nevertheless, it can be said that the repercussions of the Arab revolutions have posed and remain a major strategic challenge to the Saudi regime. After more than nine years have passed since the outbreak of the Arab revolutions in 2011, it can be said that the legitimacy crisis of the Saudi regime has increased after these revolutions, due to Riyadh's policies and the patterns of its alliances at the Arab, regional and international levels.

Saudi Arabia has taken a position in principle against all Arab revolutions, perhaps because of the traditional nature of the Saudi regime and its politically conservative orientations, which are based on rejecting the idea of revolutions and change from the bottom in general, and preferring the method of change from above, through "royal honors and grants," despite reservations. Saudi Arabia against these revolutions, as it deals with each revolution differently, based on the proximity of this or that revolution to the threat to its interests 9 .

The political developments in the Kingdom following the death of King Abdullah bin Abdulaziz and the assumption of the throne by King Salman bin Abdulaziz, and the accompanying decisions with extensive ministerial and administrative amendments, also led to a reflection on foreign policy decisions, some of which were an extension of the policies of

\footnotetext{
${ }^{5}$ A Group of Researchers, Constant and Transforming: The Gulf and the Other 2015, Gulf Center for Development Policy, pages 61-62. https://gulfpolicies.org/2019-05-18-07-30-16/2019-05-18-10-13-53/2015

${ }^{6}$ United Nations Development Program, Human Development Report 2014 Advances in Building Resilience to Managing Risk, p,234, https://www.un.org/ar/esa/hdr/hdr14.shtml

7 Abdul Mohsen Hilal, The Need for Reform in the Kingdom of Saudi Arabia, Development Forum, The 33rd Annual Meeting, Doha 2011,p,2.

${ }^{8}$ Muhammad Al-Saeed Idris, Opposing Trends: Attitudes of Non-Arab Regional Actors Toward the Arab Revolutions, Al-Siyasa Al-Dawlia Magazine, Issue 188, Cairo, Al-Ahram Center for Political and Strategic Studies, 2012,p,78.

9 Mansour Al-Marzouqi Al-Baqami, "The Saudi Position on the Arab Spring Revolutions", The Gulf in a Changing Strategic Context, Doha: Al-Jazeera Center for Studies and Beirut: Arab Science Publishers, 2014, p. 113- 132 .
} 
the previous phase, That is why the Kingdom of Saudi Arabia continued to support Egypt, which it is a pivotal country in the region, and to enable it to face the difficulties after the changes that occurred during the previous years, as the Kingdom tried to conclude a reconciliation between Egypt and

The State of Qatar, after the escalation of their differences over the background of Qatar's support for the Muslim Brotherhood - an organization that was banned in Egypt.

The Saudi intervention in Yemen also continued and, rather, developed into the creation of a coalition under international cover under the pretext of confrontation (the Houthi uprising) and protection of legitimacy, Saudi officials also demonstrated softly on some issues related to the position on armed confrontations and conflicts in Syria since 2011, while the Kingdom of Saudi Arabia sought to normalize relations with Iraq and reopen its embassy in Baghdad, after the tension in its relations for years deteriorated ${ }^{10}$.

According to the Saudi Ministry of Foreign Affairs, the priority is for the Gulf Department as it seeks to coordinate and unify common policies, especially in the security and economic side, followed by the Arab Department, as the Kingdom is keen to play the role of (supporting Arab countries) and seeking to resolve differences between them, then the Islamic Department based on the fact that Najd lands And the Hijaz are the cradles of the Muhammadiyah message, and internationally, the Kingdom seeks to interact with influential forces internationally, and to have an impact on international political and economic organizations and the oil market ${ }^{11}$, Despite the Kingdom's claim of the importance of noninterference in the affairs of other countries, it has been involved in Bahrain, Syria, and Yemen to varying degrees, believing in the necessity to exercise an effective leadership role that guarantees it leadership and continued influence.

\subsection{Kingdom of Saudi Arabia and the Arab Gulf states}

The security reality in the Arab Gulf states, in general, indicates their inability to defend themselves or to secure their protection militarily, which led to their security being found in alliance with superpowers and providing them with military facilities. The relationship of the Arab Gulf states with the major countries is interpreted as a relationship of common interests that sometimes occurs Some degree of intersection and sometimes incompatible conditions.In line with the (domino) theory, Saudi Arabia realized the strategic weakness factor in the region, and that the fall of any country in front of the wave of the revolutionary movement would lead to the fall of other countries, which generated a state of awareness of the need to move and contain to prevent the fall of the regimes allied to it, through a policy of rehabilitation on Political or economic level.

Saudi Arabia focused its interest in intensifying its activities in the Arab Gulf region in a manner that would allow avoiding the repercussions of the Arab revolutions, through the frameworks provided by the Gulf Cooperation Council, and put forward the idea of expanding the system of alliances by inviting Jordan and Morocco in 2011 to join the Council and then Gulf intervention in Bahrain on Following the February 2011 protests, then providing financial aid to the Kingdom of Bahrain and the Sultanate of Oman ${ }^{12}$. The Gulf

\footnotetext{
${ }^{10}$ A group of researchers, the Gulf in 2014-2015, the Arab Gulf Union is the future, Gulf Research Center, United Arab Emirates 2015,p, 32.

${ }^{11}$ Saudi Ministry of $\quad$ Foreign Affairs, $\quad$ Foreign $\quad$ Policy, 2013 https://www.mofa.gov.sa/KingdomForeignPolicy/Pages/ForeignPolicy24605.aspx

${ }^{12}$ Al-Saeedi Al-Abadi, The Middle East, Variables of Reality and Future Prospects, 2014, http://www.noonpost.net/content/2823
} 
Cooperation Council's call to Morocco and Jordan triggered a new phase of strategic military alliances that would have an impact on the regional and international levels.

In contrast to the "Greater Middle East Project" that extends from Morocco to Pakistan, the Gulf states announced their proactive strategy to strengthen their regional and international influence, through an axis extending from the Maghreb to Central Asia, in which Morocco, Jordan, and Pakistan play their roles to achieve this goal ${ }^{13}$.

The Kingdom of Saudi Arabia made it clear that it places the Gulf issue as a focus for it in its regional and international policy, and it gave a clear message that the principles of Saudi politics do not change because they are pronounced from a political doctrine, which is what King (Salman bin Abdul-Aziz) referred to in his speech upon assuming the reins of power, that it is consistent with the approach The Founder (Abdul-Aziz bin Abdurrahman bin Faisal bin Turki Al Saud 1932-1953) ${ }^{14}$ This dictates that the Kingdom is a more influential a party to in the form and pattern of interactions prevailing in the region.

In order to crystallize this vision, the Kingdom's policy relied on an approach in its foreign policy based on:

First: Increasing the effectiveness of its Gulf role within the framework of the Gulf Cooperation Council

The Kingdom proposed transforming the Gulf Cooperation Council into a union within the initiative of the late King Abdullah bin Abdul-Aziz at the summit of the Gulf Cooperation Council countries in Riyadh in 2011, in which he called for "to move beyond the stage of cooperation to the stage of a union to form a single entity that achieves good and pushes evil in response to aspirations." Citizens of the GCC countries and to face the challenges they face "15

Saudi Arabia's motives for proposing the idea of the Gulf Union are many, including that it was not related to the movement of change in the Arab region, as the union project was born out of a sense of imminent danger represented by the implications of the change movements and the strategic motivation associated with the Iranian expansion and the concern of the Kingdom of Saudi Arabia and the rest of the Gulf countries about the possibility of Iran exploiting the events of the region, to increase its expansion and work To penetrate its security.The self-interest or self-motivation is also represented by Saudi Arabia's desire to exploit events in its favor and push the Gulf states, worried about Iranian moves to join under its leadership, being the largest and strongest country within the joint Gulf Cooperation Council countries after more than three decades of integration attempts in a way that strengthens the GCC countries in facing future challenges ${ }^{16}$.

Second: Active involvement and influence in the neighboring regions (Iraq, Yemen, Syria, Egypt)

Strengthening the Kingdom's effective role in resolving regional conflicts in light of the deterioration of the status of some Arab countries .

13 Fouad Farhawi, The Alliance of Monarchies: The Motives of the Gulf Cooperation Council to Include Morocco and Jordan, Al Siyasa Al Dawlia Magazine, issue (185) Cairo, 2011,p,99.

${ }^{14}$ Muhammad Fahad Al-Harathi, What is happening in Riyadh, 2015, http://www.albayan.ae/opinions/articles/2015-03-04-1.2324627

15 Riyadh Declaration on 12/20/2011, General Secretariat of the Cooperation Council for the Arab Gulf States , 02

http://www.gccsg.org/index5a4e.html?action=News\&Sub=ShowOne\&ID=2240\&T=A

16 Abdul Khaleq Abdullah, Critical Dimensions: The Union of Gulf States Between Motives and Difficulties, Al Siyasa Al Dawlia Magazine, issue 196, April 2014,p,9. 


\section{Third: An attempt to balance the Iranian role in the Arab Gulf region}

By trying to impede access to the nuclear agreement between Iran and the United States, then trying to obtain nuclear technology and trying to put Pakistan in this competition by seeking to obtain nuclear technology from it or to benefit from the Pakistani armed forces in the coalition established by Saudi Arabia to fight the Houthis in Yemen.

\subsection{The Kingdom of Saudi Arabia and the countries of the region}

The Iranian concern and the competition for influence are the primary drivers of Saudi moves in the region. The Saudi decision-maker realizes that the hoped-for role collides with geopolitical factors, most notably the Saudi-Iranian competition for influence in the Arab Gulf, and Saudi Arabia's reliance on the American security umbrella, which impedes the independence of making its security and strategic decision, and the convergence of SaudiIsraeli interests as an implication about the need to confront the nuclear ambition Iranian and in a preventive measure, Saudi Arabia may resort to it with the aim of weakening the influential Iranian role in the region and containing it by pushing that towards rapprochement or even thinking about an alliance with Israel $^{17}$. British media reported the news of an alliance to establish a "moderate crescent" in the Middle East sponsored by the United States between Saudi Arabia, Jordan, the United Arab Emirates, and Israel to contain Iran instead of confronting it. According to this agreement, Israel is setting up radar stations in the Kingdom of Saudi Arabia and the United Arab Emirates to prevent Tehran from gaining any strategic advantage in the region ${ }^{18}$.

The Saudi strategic goal is to try to bring down the current regime in Syria by means of an alternative regime to it that would contribute to strengthening its regional position, as well as encircling Iraq and disrupting the advantage that Iran enjoys by encircling the Saudi judiciary ${ }^{19}$.

Therefore, it relied on a strategy in cooperation with Qatar by providing financial and military support to various Islamic organizations and working to suspend Syria's membership in the Arab League with the aim of weakening the Iranian-Syrian axis. Saudi Arabia is trying to be a major player in the region by adopting the strategy of containment and encirclement of Iran through the policy of the back door from Pakistan and surrounding it with an Islamic belt that can be extended into its territory to prevent the continuation of its regional rise, thus relying on non-state actors, opponents and armed organizations in Syria or Iraq With whom it has close ties.

According to the new data in the region, Saudi Arabia has become aware of the need to develop its regional alliances by relying on itself to face external challenges and on this level, relentless efforts have crystallized by King (Salman bin Abdul-Aziz) to build a regional alliance in the region that includes Turkey and the axis of the Sunni countries to resolve many Sticking files ${ }^{20}$.

Therefore, through the policy of alliances, Saudi tried to rearrange regional affairs on a strategic basis, as Egypt returned to the Arab arena while ensuring the provision of support to

\footnotetext{
17 A group of researchers, the Gulf in 2014-2015, the Arab Gulf Union is the future, Gulf Research Center, United Arab Emirates 2015,p, 165,

${ }^{18}$ Containing Iran': Israel 'in talks' to join alliance with Saudi Arabia, Jordan, Turkey, May 05, 2013 ,rtcom/news/israeil-iran-security-alliance-us-832/

${ }^{19}$ O MER TAŞPINAR,Turkey and Saudi Arabia: strange bedfellows in December 02, 2012 Syria, ww.todayszaman.com/.../omer-taspinar/turkey-and-sa.

${ }^{20}$ Ismail Jamal, Ankara is teetering between Tehran and Riyadh, and its decision will reshape regional alliances in the region, Al-Quds Al-Arabi newspaper, Issue (8068), London, 2015,P,10.
} 
it by the United Arab Emirates and Qatar with investment projects to advance the Egyptian economy, which has suffered greatly during the past years.

Saudi Arabia took steps to play a pivotal role in restoring relations between Egypt and Hamas after placing the movement within the terrorist organizations. With the aim of rapprochement with the Hamas movement in order to strike Iran by isolating Hamas from it, and this rapprochement is supported by the statements of the Palestinian leader (Mahmoud alZahhar) during a political seminar organized by the Center for Political and Development Studies in Gaza on March 15, 2015, saying, "Saudi Arabia leads the Gulf and is a great country in the region and seeks Due to the political changes and the Houthi movement's control of Yemen, to a good relationship with Hamas ${ }^{21}$.

Meanwhile, Saudi Arabia considered that the United States of America in 2013 launched talks with Iran because it is the issue of the Iranian nuclear file, to end a threat to its regional influence, and that it would legitimize Iran's regional ambitions ${ }^{22}$. Perhaps the countries of the Gulf Cooperation Council, especially Saudi Arabia, found strong motives to diversify strategic alliances, and to build new regional and international alliances with Russia, China and India to meet the challenges of the security environment in this era, as well as to restore balance with the United States of America in the event of any escalation threatening its vital interests in the region or threatening its security and stability.

The Kingdom of Saudi Arabia was not able to remain immune to what is happening in the countries of the region, especially the Arab ones, and developments in Yemen, which are geographically integrated with the Kingdom of Saudi Arabia, came to place it at the center of the event. Saudi Arabia has realized the importance of Yemen and considered it its "back garden" as it closely monitors matters in it, and considers security in Yemen a part of its national security and the countries of the Gulf Cooperation Council. Yemen represents a threat to the Kingdom of Saudi Arabia, so the Kingdom announced that it will take the required measures to protect its security, stability and vital interests there, Thus, Saudi Arabia looks at the developments of the Yemeni crisis, especially after the Houthis and their allies took control of most regions of Yemen in terms of reinforcing its fears about the expansion of Iran's regional influence and its control over the Strait of Hormuz, which will have repercussions on its regional interests, and control of navigation routes, so it sought to send a clear message, that it will not stand idly by About what is happening ${ }^{23}$.

In view of this, Saudi Arabia saw a real threat from the Iranian expansion attempts in Yemen that might be calculated in the balance of power in favor of Iran, and some Arab countries shared it in this, and the result is that Saudi Arabia, and behind it many countries in the region, are fighting a war for geostrategic considerations that go beyond the internal Yemeni issue.

This overall adds to Saudi Arabia many difficulties and its apprehension of the potential repercussions of the Yemeni crisis on its interests and its regional role, according to the writer Abdul Wahab Badrakhan, "Saudi Arabia could not have any other choice but to arrange the Yemeni situation, which has become a serious inconvenience to it in the future, and that the strategic position of Saudi Arabia in the Gulf has been largely declining, and this last step,

\footnotetext{
${ }^{21}$ Saudi Arabia and Iran deterrence precedes reconciliation, Al-Quds Al-Arabi newspaper, Issue 8067, April 2015, https://www.alquds.co.uk/\%ef\%bb\%bf

${ }^{22}$ ELIZABETH DICKINSON,Can Saudi Arabia’s New King Manage a Restive Middle

East,OREIGNPOLICY.COM,JANUARY 23, 2015

${ }^{23}$ Abdul Ali Hamid al-Din, The War in Yemen, Its Dimensions and Dangers, Al-Quds Al-Arabi Newspaper, Issue (8063) London, 2015,p,23.
} 
including solidarity between five Gulf countries, was formed. Some kind of attempt to correct and restore the strategic balance in the region. ${ }^{24}$ "

Rapid events have led to the realization of the Saudi leadership and its allies from the Gulf states that they must make up their minds about interfering in Yemen, affirming not to allow the Iranian tide to control the Bab al-Mandab Strait and control navigation in the Arabian Sea and the Red Sea, which threatens many Arab regional interests and makes them under their control and its influence.

In order to contain the new reality, Saudi Arabia moved to the position of the initiator, not the one expected, to intervene in Yemen in order to adjust the balance of the decline in its regional and internal weight, which is simply the first serious Saudi attempt to balance what happened in the nineties of the last century, and this is a major change in the features of Saudi policy in the region, which was Within its regional movement, it is satisfied with moving its allies in the region, or providing them with money or weapons through intermediaries, and its movement has always been framed by cautious policies, so the war of the Arab coalition led by Saudi Arabia against the Houthis and the forces loyal to the former Yemeni president (Ali Abdullah Saleh) in Yemen marks the beginning of a phase A new Arab region in which Saudi Arabia and some of its allies in the Arab Gulf, with the exception of the Sultanate of Oman, are withdrawing from their retreat into a player in mutual geopolitical equations in the region and their capabilities for action and reaction ${ }^{25}$.

The Saudi role is nothing but a serious attempt to shift from a policy of negative neutrality regarding regional issues to a policy of initiatives, and this began to be evident in the Yemeni crisis to restore and correct balances in the region and suggest an end to the Iranian extension.

\section{Conclusion}

The data contained in the research indicate that since 2010, the changes in the regional environment have pushed the Kingdom of Saudi Arabia to reconsider some of the problems and challenges to which its policy was exposed, and on the level of visions and perceptions it has moved towards searching for what it deems best to enhance its security and stability in the region.

Therefore, the need to adapt in the formation of its approval towards regional issues, in line with the changes that occurred in the structure of the Arab regional system and the decline of the position of some regional actors, which led to the multiplicity of Saudi regional proposals to formulate its strategic directions to confront the state of imbalance in the region, in addition to that. Its keenness to fulfill its obligations towards its regional allies, as is the case in Yemen.

The Kingdom of Saudi Arabia has reported that it is an effective regional state and has emerged more powerful in dealing with crises. The country was the least affected by the wave of transformations in the region. This role is not limited only to political influence, but also includes cultural and religious dimensions for what it has a position in the Islamic world and emerged more able to understand how Dealing with the regional environment.

\footnotetext{
${ }^{24}$ Saudi Arabia Moves Against the Houthis To Save Its Regional Weight, Ray Al-Youm Electronic Newspaper, International Information Network, March, 2015 https://www.raialyoum.com/\%3Fp\%3D235920,

${ }_{25}$ Saudi Arabia and Iran deterrence precedes reconciliation, Al-Quds Al-Arabi newspaper, Issue 8067, April 2015, https://www.alquds.co.uk/\%ef\%bb\%bf
} 


\section{References}

Abdul Ali Hamid al-Din, The War in Yemen, Its Dimensions and Dangers, Al-Quds Al-Arabi Newspaper, Issue (8063) London, 2015,p,23.

Abdul Khaleq Abdullah, Critical Dimensions: The Union of Gulf States Between Motives and Difficulties, Al Siyasa Al Dawlia Magazine, issue 196, April 2014,p,9.

A group of researchers, the Gulf in 2014-2015, the Arab Gulf Union is the future, Gulf Research Center, United Arab Emirates 2015,p, 165,

Al-Saeedi Al-Abadi, The Middle East, Variables of Reality and Future Prospects, 2014, http://www.noonpost.net/content/2823

Abdul Mohsen Hilal, The Need for Reform in the Kingdom of Saudi Arabia, Development Forum, The 33rd Annual Meeting, Doha 2011,p,2.

Containing Iran': Israel 'in talks' to join alliance with Saudi Arabia, Jordan, Turkey, May 05, 2013 ,rtcom/news/israeil-iran-security-alliance-us-832/

ELIZABETH DICKINSON,Can Saudi Arabia's New King Manage a Restive Middle East,OREIGNPOLICY.COM,JANUARY 23, 2015

Fouad Farhawi, The Alliance of Monarchies: The Motives of the Gulf Cooperation Council to Include Morocco and Jordan, Al Siyasa Al Dawlia Magazine, issue (185) Cairo, 2011,p,99.

Ismail Jamal, Ankara is teetering between Tehran and Riyadh, and its decision will reshape regional alliances in the region, Al-Quds Al-Arabi newspaper, Issue (8068), London, 2015,P,10.

Madawi Al-Rasheed, "The Future of Reform Demands in Saudi Arabia," Beirut: Center for Arab Unity Studies and the Swedish Institute in Alexandria, January 2016, p. 671.

Mansour Al-Marzouqi Al-Baqami, "The Saudi Position on the Arab Spring Revolutions", The Gulf in a Changing Strategic Context, Doha: Al-Jazeera Center for Studies and Beirut: Arab Science Publishers, 2014, p. 113- 132.

Muhammad Al-Saeed Idris, Opposing Trends: Attitudes of Non-Arab Regional Actors Toward the Arab Revolutions, Al-Siyasa Al-Dawlia Magazine, Issue 188, Cairo, AlAhram Center for Political and Strategic Studies, 2012,p,78.

Muhammad Abdul Salam, How will relations be managed in the next stage, Al Siyasa Al Dawliya magazine Issue 186, Al-Ahram Institute for Strategic Studie.

Muhammad Fahad Al-Harathi, What is happening in Riyadh, 2015, http://www.albayan.ae/opinions/articles/2015-03-04-1.2324627

O MER TAŞPINAR,Turkey and Saudi Arabia: strange bedfellows in December 02, 2012

Syria, ww.todayszaman.com/.../omer-taspinar/turkey-and-sa.

Salih Al-Nu'mani, The Israeli Strategic Mind: A Reading in the Arab Revolutions and an Examination of Their Fate Beirut, Arab House,2013,p,32. https://www.elsiyasaonline.com/2020/01/The-Israeli-Strategic.html

Saudi Arabia and Iran deterrence precedes reconciliation, Al-Quds Al-Arabi newspaper, Issue 8067, April 2015, https://www.alquds.co.uk/\%ef\%bb\%bf

Saudi Arabia Moves Against the Houthis To Save Its Regional Weight, Ray Al-Youm Electronic Newspaper, International Information Network, March, 2015 https://www.raialyoum.com/\%3Fp\%3D235920,

Saudi Ministry of Foreign Affairs, Foreign Policy, 2013 https://www.mofa.gov.sa/KingdomForeignPolicy/Pages/ForeignPolicy24605.aspx

United Nations Development Program, Human Development Report 2014 Advances in Building Resilience to Managing Risk, p,234, https://www.un.org/ar/esa/hdr/hdr14.shtml. 